\title{
Jerzy Nikitorowicz: \\ Edukacja międzykulturowa w perspektywie paradygmatu współistnienia kultur. Białystok 2020, Wydawnictwo Uniwersytetu w Białymstoku, ss. 261 ISBN: 978-83-7431-633-0
}

Jako społeczeństwo mierzymy się od lat zarówno ze zjawiskiem migracji (zwłaszcza zarobkowej), jak i uchodźctwa - nie jesteśmy krajem monokulturowym (co niestety nie wszyscy sobie uświadamiają). Stąd tak ważne są teraz opracowania z zakresu edukacji międzykulturowej. Na pewno część regionów Polski ma własne, bogatsze niż inne doświadczenia wynikające $\mathrm{z}$ bycia środowiskiem zróżnicowanym kulturowo. Wyrastanie w takim regionie z pewnością sprzyja budowaniu wrażliwości na problemy Innego, wyostrza zmysły obserwowania świata, by wychwytywać to, co może budzić niepokój. Sądzę, że tak jest w przypadku Jerzego Nikitorowicza, którego kolejne publikacje są świadectwem nie tylko reagowania na to, co można zaobserwować w dzisiejszym świecie i co może budzić niepokój, ale również wskazywania na te zjawiska, które są istotne ze względu na to, co będzie $\mathrm{w}$ przyszłości szczególnie istotne w wymiarze indywidualnym i społecznym. Ciągle aktualne i być może ważniejsze niż w momencie wygłaszania jest stwierdzenie Tadeusza Lewowickiego: „(...) edukacja międzykulturowa, jest konstruktywną odpowiedzią na wiele ważnych wyzwań wobec społeczeństw współczesnej Europy - a także polskiego społeczeństwa. Przede wszystkim edukacja międzykulturowa - jak w ogóle edukacja - służy i powinna służyć wydobyciu z ludzi najlepszych stron człowieczeństwa" (2002, s. 39). Jest ona jednym z czynników ułatwiających radzenie sobie z problemami społecznymi, będącymi pochodną różnic międzyludzkich i stanowi podstawę do wzajemnego poznania czy kształtowania postaw nastawionych na tolerancję czy akceptację. Ważna jest świadomość, że edukacja międzykulturowa to nie tylko teoria, ale równie ważny, a może nawet ważniejszy jest jej praktyczny wymiar, co podkreślał Jerzy Nikitorowicz w swoich wcześniejszych publika- 
cjach, twierdząc: „istotą edukacji międzykulturowej jest wprowadzić dziecko jak najwcześniej w ustawiczny dialog ze sobą i swoją kulturą oraz z innymi reprezentantami rodzimej kultury" (2005, s. 33).

Jak zauważa Marian Kempny - w myśleniu o współczesnym świecie i skutkach globalizacji dominują dwa główne nurty refleksji. Pierwszy - ekonomizm - odwołuje się do światowego kapitalizmu i przemian gospodarczych, a drugi - kulturalizm - skupia się na przemianach kulturowych (2001, ss. 70-101). Przygotowana przez Jerzego Nikitorowicza publikacja sprzyja refleksji nad codziennością w świecie zróżnicowanym kulturowo. Pozwala czytelnikom dostrzec, że prezentowane zagadnienie nie są czymś dalekim, a wręcz przeciwnie dotyczą każdego z nas - i można odnieść wrażenie, że z każdym rokiem, przynoszącym kolejne zmiany, staje się to bardziej aktualne. Opracowanie ma charakter poznawczy, dostarcza licznych informacji na temat edukacji międzykulturowej, ale co warto podkreślić - sam jej zamysł, sposób przygotowania, opracowania sprawia, że czyta się ją z ogromną przyjemnością. Autor podkreśla, że w obecnych czasach niezbędne stało się nadanie szczególnej wartości dialogowi kultur. Społeczeństwa w coraz większym stopniu stają się wielokulturowe i to nie różnica przyczynia się do narastania konfliktów, lecz brak działań zmierzających do poznawania się, budowania tolerancji, zrozumienia, wzmacniania kompetencji międzykulturowych i komunikacyjnych - mających na celu porozumienie między członkami reprezentującymi różne grupy. To właśnie aktualne zadania edukacji międzykulturowej i pedagogów, którzy na bieżąco śledzą sytuację związaną z migracjami, niepokojącymi zjawiskami towarzyszącymi, jak narastający fanatyzm, nacjonalizm czy ksenofobia.

Antonina Kłoskowska podkreślała, że niezbędną wartością we współczesnym świecie jest otwartość kultur - warto zauważyć za Autorką, że nie oznacza to braku selekcji przyswajanych wpływów i ich bezkrytycznej akceptacji. Budowanie nowej przestrzeni międzykulturowej ma miejsce tylko w sytuacji życzliwego zwrócenia się w stronę innych kultur, personalistycznego spojrzenia na inne społeczeństwa (tym samym na poszczególne jednostki tworzące to społeczeństwo). Przyswajanie wartości innych kultur powinno odbywać się na zasadzie otwartości, której towarzyszy życzliwy krytycyzm, z jednoczesnym akceptowaniem i akcentowaniem przynależnego prawa każdego człowieka do wolności (A. Kłoskowska 2002, s. 159). Czytając recenzowaną pracę, trudno oprzeć się wrażeniu, że jej Autorowi towarzyszyła w trakcie pisania przywołana za Antoniną Kłoskowską refleksja, która znajduje swoje odzwierciedlenie w monografii - już na etapie zadań, stawianych 
przed edukacją międzykulturową, sformułowanych przez Jerzego Nikitorowicza we Wprowadzeniu (2020, ss. 13-14).

Opracowanie zostało podzielone na 11 wzajemnie się dopełniających rozdziałów. Autor rozpoczyna rozważania od przedstawienia czytelnikom swoistego vademecum wiedzy na temat wielokulturowości - samej idei, jej roli w uprawianiu określonej polityki (pokazane na przykładzie między innymi modelu w USA, Kanadzie czy Australii). Wskazuje źródła kryzysu idei i wizji społeczeństw wielokulturowych (ss. 19-20), a jednocześnie podkreśla znaczenie edukacji międzykulturowej. Ważne miejsce w I rozdziale zajmują też takie kategorie jak etos, wartości czy tożsamość - jest to swoiste wprowadzenie w zagadnienia, które zostały szerzej zaprezentowane w kolejnych rozdziałach monografii. W rozdziale poruszone zostało również zagadnienie (nowej) polityki wielokulturowości (ss. 26-27) i wskazany istotny problem, jakim wydaje się być przestrzenne zachowanie człowieka w kontekście konfrontacji kultur (ss. 29-30). W drugim rozdziale Autor opisuje najważniejsze, z jego perspektywy, wyzwania stojące przed edukacją międzykulturową. Między innymi zwraca uwagę na konieczność uwzględniania w edukacji międzykulturowej perspektywy emancypacyjnej, która doprowadziła do rezygnacji z ukrywania odmienności kulturowej, do odbudowy wartości, które wcześniej były ukrywane, pozwoliła na rezygnację z udawania czy kreowania tożsamości rozszczepionej czy schizofrenicznej. Podkreśla istotę polifoniczności, z której nie można zrezygnować, gdyż nie ma możliwości zatrzymania postępującego zróżnicowania w różnych wymiarach i warstwach funkcjonowania człowieka i jego kultury (ss. 36-37). Za szczególne wyzwania stojące przed edukacją międzykulturową Autor przyjmuje przeciwdziałanie utracie polifonii w procesie kształtowania tożsamości narodów (s. 37), zwrócenie uwagi na proces kreowania otwartej polityki wielokulturowości. W kolejnych dwóch rozdziałach Autor uszczegóławia sposób traktowania wielokulturowości jako faktu empirycznego, wskazując na potrzebę jej zaprezentowania w aspekcie historycznym - od procesów kształtowania się I Rzeczypospolitej do ukazania tożsamościowych dylematów obywateli państw, które powstały po rozpadzie ZSRR. Jerzy Nikitorowicz zwraca tu między innymi uwagę na odpowiedzialność edukacji międzykulturowej w zakresie poznania i interpretacji tradycji I Rzeczypospolitej, do której mają prawo również się odwoływać Białorusini, Litwini czy Ukraińcy, ale także Żydzi i inne narody funkcjonujące w jej granicach. Dostrzega wiele problemów tożsamościowych (w tym Polaków, zamieszkujących inne państwa) po rozpadzie ZSRR i zwraca uwagę na koncepcję transkulturowości. 
Ważne miejsce zajmuje w przygotowanej przez Jerzego Nikitorowicza publikacji pokazanie praktycznych egzemplifikacji działań realizowanych w środowisku zróżnicowanym kulturowo. Istotne jest bowiem ukazywanie realnych problemów - ludzi pogranicza, złożoność kreowania ich tożsamości, czy podejmowanych wyborów. To dostrzeganie i eksponowani tzw. „dobrej pamięci”, ale również wskazywanie i analizowanie w kontekście „współczynnika humanistycznego” „złej pamięci”. Ciekawym zabiegiem wzbogacającym opisy jest zamieszczenie fragmentów pamiętnika Henryka Ciecierskiego, obrazujących problemy tożsamościowe ludzi pogranicza kultur w pierwszych latach II Rzeczypospolitej. Jerzy Nikitorowicz wskazuje również na inne znaczące w dziejach naszej kultury sylwetki ludzi pogranicza, których tożsamość kształtowała się w obrębie dwu lub większej liczby kultur (ss. 99-117).

Autor dostrzega również znaczenie zagadnienia wielości kultur w dialogu tożsamościowym. Dialog powinien zmierzać do przełamania barier, lęków, uprzedzeń, stereotypów w duchu twórczego spotkania, a nie obojętności czy wrogości (s. 125), może być traktowany jako nieskończona rozmowa z samym sobą i równolegle z innymi, gdy pragnie się coś zrozumieć i odnaleźć sens, co jest szczególnie istotne w sytuacji nabywania kompetencji międzykulturowych czy świadomości inkluzyjnej. W rozdziale Autor definiuje również kategorię ustawicznie kształtującej się tożsamości (ss. 127-128), odwołuje się do typów tożsamości i zwraca uwagę na kształtowanie tożsamości jako problemu egzystencjalnego, łączącego się z problemem rozwoju indywidualnego, więzi grupowych, ale także potrzebami warunkowanymi rozwojem indywidualnym i społeczeństwa. Warto zwrócić w rozdziale uwagę na rozważania Jerzego Nikitorowicza w odniesieniu do autobiograficznej pracy Piotra Lachmanna (1999), niezwykłego, a rzadko przywoływanego życiorysu Wojciecha Korfantego czy Marca Szeftela. W rozdziale VII Autor charakteryzuje sposoby dialogu i opisuje jego rolę zarówno w zakresie rozwoju indywidualnego, jak i w wymiarze społecznym, np. w procesie kształtowania i promowania pokoju (s. 143). Bardzo trafnym zabiegiem, wzmacniającym przekaz, jest przywołanie dziejów wybranych rodzin i ich poszczególnych członków. Dzięki temu możemy zwrócić uwagę nie tylko na złożone historie wielu osób i ich rodzin, ale również trajektorię życia człowieka, czynniki warunkujące stosunek do świata, i do siebie samego, czy umożliwiające przetrwanie kryzysów czy różnorodnych przeciwności losu (ss. 144-153).

W kolejnym rozdziale Autor słusznie zauważa, że mamy do czynienia z sytuacją, gdy coraz więcej uwagi przywiązuje się do rozwoju systemu ekonomicznego, rozwoju militarnego, a coraz mniej uwagi poświęca się po- 
stawom obywatelskim, poczuciu solidarności czy zachodzącym procesom dehumanizacji. To przyczynia się do stawiania przed edukacją międzykulturową nowych wyzwań i zadań. Wskazuje na niebezpieczeństwa związane z zauważalnym coraz bardziej tworzeniem i uczestniczeniem ludzi w trzech kulturach, budujących tak negatywne zjawiska jak terroryzm i ekstremizm, czy marginalizację i separatyzm - ilustracją są do tego przywoływane przykłady z ostatnich lat, zarówno europejskie (np. z Holandii), jak i polskie, np. obława augustowska, nagłaśniana w mediach postać „Burego” i w tym kontekście historia wielu żołnierzy wyklętych (ss. 175-177). Mamy obecnie bardzo mocno nasycone ideologicznie media, a przekazy formułowane przez osoby znaczące w państwie, ale również w Kościele, świadczą o niezauważaniu, a może świadomym pomijaniu i deprecjonowaniu lokalnych problemów pamięci indywidualnej i zbiorowej. Autor stawia pytania dotyczące przyszłości naszego społeczeństwa: „Czy nasze społeczeństwo stanie się bardziej wrażliwe, mniej megalomańskie i ksenofobiczne, myślące humanistycznie czy będziemy zmierzać ku dehumanizacji i infrahumanizacji?" (s. 179). Odpowiedzią jest dialog, rozumienie i interpretacja takich istotnych pojęć, jak np. patriotyzm, ale również kultura i sztuka (przewodnie kategorie rozdziału IX). Obok analizy teorii kultury i sztuki ważne miejsce zajmują tu działania w środowisku - uwrażliwiające na odmienność kulturową (Autor wskazuje tu na kilka z nich, np. spektakl "Sąsiedzi, których nie ma”, s. 186, festiwale muzyczne, np. Międzynarodowy Festiwal Muzyki Cerkiewnej „Hajnówka” w Białymstoku, ss. 190-191).

Ważne miejsce w rozważaniach Jerzego Nikitorowicza zajmuje pamięć zbiorowa ujmowana w kontekście bezpieczeństwa kulturowego. Autor wychodzi z założenia, że obecnie mamy do czynienia z dominacją emocji i marginalizacją wiedzy, a jednym z ważnych wymiarów antagonizowania się kultur i ludzi je reprezentujących jest zjawisko pamięci zbiorowej, wyzwalające różny poziom poczucia bezpieczeństwa kulturowego (s. 197). Mamy sytuację, w której zauważalny jest nadmiar pamięci o pewnych wydarzeniach, a z drugiej niedobór o innych - pojawia się tu kategoria oporu i przymusu powtarzania (s. 198). Ważne miejsce w rozdziale zajmują rozważania dotyczące pamięci zbiorowej (odwołania do prac Kwiatkowskiego i Szackiej), ale także analiza za Michaelem Foucault powiązania pamięci zbiorowej z władzą (ss. 200-201), zwrócenie uwagi na rolę mediów (zwłaszcza publicznych), tworzących tzw. pamięć popularną. Jerzy Nikitorowicz przywołuje przykłady wypowiedzi mieszczące się w nurcie „pamięci przeciwnej” traktowanej często jako pamięć grup mniejszościowych (jest to pamięć nie zawsze uwzględnia- 
na w głównej pamięci), posiadająca swoje źródło w społeczności lokalnej. Pamięć tego typu zwraca uwagę na inne doświadczenia, które są najczęściej pomijane przez główny nurt pamięci. W rozdziale znajdujemy bardzo ciekawy wątek związany z historią rodziny Skirmuntów - wart do rozpatrzenia $\mathrm{w}$ kategorii zagadnień do wykorzystania w praktyce edukacyjnej jako przykłady „dobrej pamięci” (ss. 211-212).

Publikację zamyka rozdział, w którym Autor zwraca uwagę na fakt, że obecnie działania edukacyjne powinny skupić się na problemach, między innymi: jak pogodzić edukację w państwach narodowych z kształtowaniem się społeczeństw wielokulturowych, patriotyzm narodowy z patriotyzmem obywatelskim, prawa i zasady życia gospodarzy z oczekiwaniami i potrzebami przybyszów - imigrantów, jak organizować sytuacje stymulujące rozwój systemów wartości wspierających rozwój człowieka w warunkach wielokulturowości, jak kształtować więzi i poczucie wspólnoty, odpowiedzialności za zachowanie człowieka w kształtowanej przez niego przestrzeni społeczno-kulturowej? W rozdziale znajdujemy kolejne interesujące odwołanie do nietuzinkowych życiorysów, w których można zauważyć problem poczucia obywatelstwa związany ze stanem psychicznym (nie bać się, nie czuć się zniewolonym, nie odczuwać presji, że jestem inny, gorszy, niepotrzebny, kłopotliwy itp.). Jerzy Nikitorowicz wskazuje, że istotne jest formułowanie i podejmowanie przez edukację: „jak pogodzić edukacje w państwach narodowych z kształtowaniem się społeczeństw wielokulturowych, patriotyzm narodowy z patriotyzmem obywatelskim, prawa i zasady życia gospodarzy z oczekiwaniami i potrzebami przybyszów - imigrantów (...) (s. 220). Równie ważne jest wskazanie, czym jest tolerancja, która - zdaniem Autora - nie domaga się rezygnacji z własnych opinii, sądów czy norm, nie oznacza też konieczności powstrzymywania się w wyrażaniu własnego zdania, wręcz przeciwnie, domaga się głoszenia własnych sądów, z jednoczesnym dopuszczeniem innych do ich przedstawiania, szacunkiem do nich i prezentowanej przez innych odmienności spojrzenia i interpretacji. Ważna jest jednak wiedza o granicach tolerancji, gdyż nie można być tolerancyjnym na przykład wobec nienawiści rasowej czy deprawowania nieletnich (s. 231). Tolerancja to wysiłek światopoglądowy dwóch stron, świadome działanie zmierzające do ustawicznej negocjacji w dialogu.

Książka Edukacja międzykulturowa w perspektywie paradygmatu wspótistnienia kultur jest bardzo cenną pozycją. Wydaje się to być ważne zwłaszcza dziś, gdy zróżnicowanie kulturowe stało się elementem codzienności, a jednocześnie tak mocno widoczne są przejawy zachowań wskazujących na 
brak wiedzy i chęci poznania Innego. Jej atutem jest rozpatrywanie problematyki z perspektywy teoretycznej i praktycznej, gdyż dzięki przystępnemu i niezwykle dobrze trafiającemu do Czytelnika językowi książka ta dostarcza również niewprawnym w czytaniu tekstów naukowych tak potrzebnej wiedzy dotyczącej środowiska zróżnicowanego kulturowo i założeń edukacji międzykulturowej. Cennym zabiegiem są liczne odwołania do postaci - mniej lub bardziej znanych, których biografie są znakomitą ilustracją do rozpatrywanych zagadnień. Sformułowana przez Jerzego Nikitorowicza teza: „nikt nie jest »zakładnikiem « kultury pochodzenia przodków" jest gotowym mottem na cykl zajęć dla studentów, nauczycieli i uczniów. Uważam, że publikacja może stanowić znakomity materiał do dyskusji i opracowań, by stać się materiałem pomocniczym dla nauczycieli do realizowania zajęć w szkołach z zakresu edukacji międzykulturowej. We Wprowadzeniu autor napisał: „W pracy chciałbym zwrócić uwagę i uświadomić wartość edukacji międzykulturowej $\mathrm{w}$ procesie kształtowania paradygmatu współistnienia w dzisiejszym świecie ponowoczesnym, w świecie rozchwianych, wielorakich i zróżnicowanych wartości i reguł” (s. 14). Z całą pewnością zakładany przez Autora cel należy uznać za osiągnięty.

\section{Bibliografia}

Kempny, M. 2001. Globalizacja kultury i ulokalnienie tożsamości? Procesy kulturowe w teoretycznym dyskursie współczesnej socjologii. W: Jawłowska, A. red. Wokót problemów tożsamości. Warszawa: Wydawnictwo LWT, ss. 79-101.

Kłoskowska, A. 2002. Kultury narodowe wobec globalizacji a tożsamość jednostki. Kultura i Społeczeństwo. 2, ss. 155-173.

Lachmann, P. 1999. Wywołane z pamięci. Olsztyn: „Borussia”.

Lewowicki, T. 2002. W poszukiwaniu modelu edukacji międzykulturowej. W: Malewska, E. i Śliwerski, B. red. Pedagogika i edukacja wobec nowych wspólnot i różnic w jednoczacej się Europie. Kraków: Oficyna Wydawnicza „Impuls”, ss. 23-39.

Nikitorowicz, J. 2004. Dialog kultur w społeczeństwie wielokulturowym i w działaniach edukacji międzykulturowej w kontekście integracji. W: Paszko, A. red. Edukacja międzykulturowa w Polsce na przełomie XX i XXI wieku Kraków: Wojewódzka Biblioteka Publiczna w Krakowie, ss. 13-30.

Nikitorowicz, J. 2005. Próba określania przedmiotu edukacji międzykultu- 
rowej. W: Nikitorowicz, J., Misiejuk, D. i Sobiecki, M. red. Region. Tożsamość. Edukacja. Białystok: Wydawnictwo Uniwersyteckie „Trans Humana", ss. 15-33.

Nikitorowicz, J. 2020. Edukacja międzykulturowa w perspektywie paradygmatu wspótistnienia kultur. Białystok: Wydawnictwo Uniwersytetu w Białymstoku. 